\title{
Effect of E-Marketing on Purchase Decision Musicool Product of PT. Pertamina (Persero) RU III Palembang
}

\author{
Ferdi Kurniawan, Zakaria Wahab, Marlina Widiyanti, Muchsin Saggaff Shihab
}

\begin{abstract}
The purpose of this study is to analyze the effect of e-marketing through online media pada akun Instagram @musicoolpertamina, mobile applications Musicool Promo Official, websites www.musicoolpromo.com, and youtube account pertamina used by PT. Pertamina (Persero) to market or promotion its product, namely musicool. The data collected in this study were questionnaire data made using Google Form with 5 statement / indicator for variable convenience (X 1), 6 statement / indicator for variable content (X 2), 5 statement / indicator for variable response ( $X$ 3), 6 statement / indicator for variable security (X 4), 7 statement / indicator for variable trsut $(X$ 5) and 10 statement / indicator for variable purchase decision $(Y)$ and then distributed to one hundred respondents who is domiciled in Palembang, Indonesia via direct messages, e-mails and short messages (whatsapp). Multiple linear regression with SPSS software version 26 was used to analyze the collected data. The results showed positives and significant effects between the variable of convenience $(X 1)$ on purchasing decisions, variable of content (X2) on purchasing decisions, variable of responses (X3) on purchasing decisions, variable of security $(X 4)$ on purchasing decisions and variable of trust (X5) on purchasing decisions $(Y)$ in e-marketing Musicool Product of PT. Pertamina (Persero) RU III in Palembang.
\end{abstract}

Keywords: E-Marketing, Purchase Decisions, Musicool

\section{INTRODUCTION}

\section{A} According to A Sussanto (2014), a purchase decision is a process in which certain stages are involved in purchasing a product, while according to Kotler and Amstrong (2018) in the evaluation stage, consumers form preferences between brands in a series of choices and may also form the intention to buy the most brands. Preferred Rizana, Zakaria and Marlina (2020) explain that decisions of purchasing is an action taken by a consumer to purchase a product or service. The process of selecting one of the problem solving solutions with real follow-up is one of the definitions of decision making. After the decision is made, the consumer re-evaluates the options, so that in the end they can decide

Revised Manuscript Received on January 15, 2021.

* Correspondence Author

Ferdi Kurniawan*, Student MagisterxManagement, Economic Faculty of Sriwijaya Univeristy , Palembang , Indonesia. Email: k.ferditz@gmail.com

Zakaria Wahab, Lecturer of Magister iManagement Economic Faculty, Sriwijaya University, Palembang Indonesia

Marlina Widiyanti, Lecturer of iMagister management Economic Faculy, Sriwijaya University, Palembang Indonesia

Muchsin Saggaff Shihab, Lecturer of Magister management Economic

(C) The Authors. Published by Blue Eyes Intelligence Engineering and Sciences Publication (BEIESP). This is an open access article under the CC BY-NC-ND license (http://creativecommons.org/licenses/by-nc-nd/4.0/) Faculy, Sriwijaya University, Palembang Indonesia

what to do next.

According to Immanuel (2019) purchasing decisions in e-marketing are influenced by causal factors, content, response, security and trust.

\section{LITERATURE REVIEW}

\section{A. Definition of E-Marketing}

Ryan et al. (2009) explain that all efforts made to market products or services through electronic media or the Internet are Internet Marketing (English: Internet marketing, e-marketing, or online-marketing). It was further explained that the letter ' $e$ ' in the word e-marketing has an electronic meaning. This means that marketing activities are carried out electronically through the internet network. With internet technology, many new terms use the prefix e, such as: e-mail, e-business, e-gov, e-society, etc.

\section{B. Definition of Purchase Decision}

Kotler \& Armstrong (2004) said that a stage of the decision process where consumers actually make a product purchase is a purchase decision. Prior to a transaction, there are processes that occur and accompany every purchase, namely considerations. Meanwhile, according to Swastha (2002) a purchase decision is a series of stages experienced by consumers to experience a decision to buy a product.

\section{Conceptual Framework}

Juliandi \& Irfan (2013) stated that the conceptual framework is a scientific explanation of the propositions between the linkages or the relationships between research variables. It is important to put forward the link or relationship between these variables as a basis for formulating research. To clarify the relationship between the variables described, it can be seen in the conceptual framework in Figure 1 as follows:

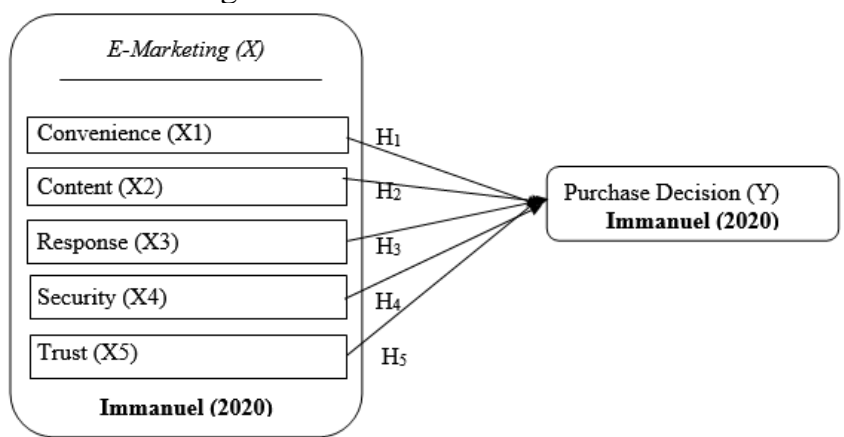

Source : Developed for this research, 2020

Figure 1. Conceptual Framework

Published By:

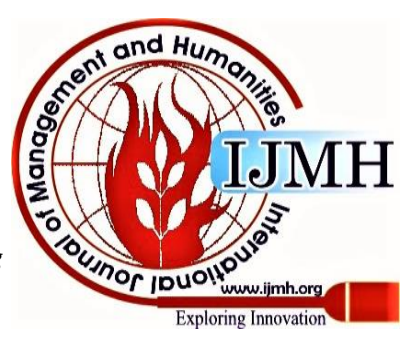

Blue Eyes Intelligence Engineering and Sciences Publication (c) Copyright: All rights reserved. 


\section{Effect of E-Marketing on Purchase Decision Musicool Product of PT. Pertamina (Persero) RU III Palembang}

Research Hypothesis

$\mathrm{H} 1$ : Convenience of variables in e-marketing has a positive effect on purchasing decisions for Musicool PT products. Pertamina (Persero)

$\mathrm{H} 2$ : Content of variables in e-marketing has a positive effect on purchasing decisions for Musicool PT products. Pertamina (Persero)

H3 : Response of variables in e-marketing has a positive effect on purchasing decisions for Musicool PT products. Pertamina (Persero)

H4 : Security of variables in e-marketing has a positive effect on purchasing decisions for Musicool PT products. Pertamina (Persero)

$\mathrm{H} 5$ : Trust of variables in e-marketing has a positive effect on purchasing decisions for Musicool PT products. Pertamina (Persero)

\section{RESEARCH METHODS}

\section{A. Method}

The scope of this research discusses the effect of the application of e-marketing on purchasing decisions of PT. Pertamina (Persero) Musicool products. Consumers who want to be studied are consumers who have used PT.Pertamina (Persero) 's Musicool product platform media.

\section{B. Types of research}

Based on the type, there are two types of data collected from this study, namely primary data and secondary data. Primary data is data obtained from questionnaires distributed to consumers using Musicool products, while secondary data is data obtained from documents, research reports and internet websites that support primary data.

\section{Population and Sample}

In this study the population is musicool consumers who live in Palembang and follow Pertamina's e-marketing media platform such as on the Instagram @Musicoolpertamina social media, amounting to 985 followers, and on the youtube account@pertamina, which amounted to 44.3 thousand subscribers.

From this population, a number of samples were determined that focused on Instagram account followers for Musicool products and YouTube subscribers for Musicool products who live in Palembang.

\section{Method of collecting data}

Collecting data in this study using observation techniques, namely observing directly the phenomena associated with e-marketing (Instagram, YouTube, mobile application and the Musicool website) and purchasing decisions using Musicool in Palembang to complete the primary data obtained through questionnaires. Questionnaires, namely data collection methods carried out by providing a list of statements or questions (questionaire) to respondents with an answer choice guide. Statements or questions related to the relationship of E-marketing and purchasing decisions using Musicool in Palembang are used as a guide to the answers to the questionnaire in this study.

\section{E. Data analysis technique}

In order to provide an overview and answer the problem formulation, quantitative descriptive analysis was used as a data analysis technique in this study. Multiple linear regression analysis used as a data analysis technique to answer the problems raised in this study

\section{F. Validity test}

To measure the validity of the instrument items from the 5 variables in this study, namely the Ease (X1) variable, the Content variable (X2), the Response variable (X3), the Security Variable (X4) and the Trust variable (X5) and the purchase decision variable (Y) were carried out. instrument trial of 30 people.

\section{G. Reliability test}

Reliability is defined as the level of confidence in the measurement results. The size of the reliability level is empirically indicated by a number, known as the reliability coefficient. The statistical test that can be used in determining the level of internal reliability of a measuring instrument is the Cronbach Alpha test using the SPSS (Statistical Program for Social Science) version 26.00 or the latest version. In testing the reliability of the five variables in this study, namely the variable Security, Trust, Response, Ease, Content and Purchasing Decision variables that need to be considered is the value of Reliability Coefficients (Cronbach's Alpha). If the Cronbach's Alpha value is greater than 0.60 (Alpha> 0.6 ), then the measured variable is reliable (Sugiyono, 2012). Research Data Analysis

To prove whether there is a causal relationship between independent variables and related variables, the analysis tool to predict the value of the effect or more independent variables on one dependent variable is multiple linear regression. The multiple linear regression equation is formulated as follows:

$$
\mathrm{KB}=\alpha+\beta_{1} \mathrm{KM}+\beta_{2} \mathrm{KT}+\beta_{3} \mathrm{RP}+\beta_{4} \mathrm{KA}+\beta_{5} \mathrm{KP}+\mathrm{e}
$$

$\mathrm{Y}=$ PurchaseDecision $(\mathrm{KB})$

$\mathrm{X} 1$ = Convenience $(\mathrm{KM})$

$\mathrm{X} 2$ = Content $(\mathrm{KT})$

$\mathrm{X} 3=$ Response $(\mathrm{RP})$

$\mathrm{X} 4$ = Security $(\mathrm{KA})$

$\mathrm{X} 5=$ Trust $(\mathrm{KP})$

$\alpha=$ Constant

$b_{1}, \ldots, b_{4}=$ independent variable regression coefficient

e $=$ Standard Error

\section{H. Classic assumption test}

There are several tests of basic assumptions in the multiple linear regression model equation, this aims to assess a model with the intention of finding out whether the regression equation specified is a model that can produce unusual estimates.

\section{Normality test}

According to Winarno (2015) the normality test aims to prove whether in the regression model confounding or residual variables have a normal distribution. Decision making depends on the value of the Kolmogorov Smirnov test.

Decisions can be made if the Kolmogrov test is not significant (less than two), so the data is normally distributed or if the probability is greater than 0.05 , the data is normally distributed. 


\section{J. Multicollinearity test}

The purpose of the multicollinearity test is to determine whether there is a significant relationship between the independent variables. How to detect multicollinearity is independent variables in the model. Multicollinearity testing is very dependent on the value of R-Square, F-count and standard error. If there is no problem with multicollinearity, then H0: R-square $<$ R-square value of the main model. If there is a problem with multicollinearity then H1: R-square value> main model $\mathrm{R}$-square value.

\section{K. Heteroscedasticity test}

The heteroscedasticity test aims to determine whether there is a problem with heteroscedasticity by using the white heteroscedasticity test. If there is no heteroscedasticity, then $\mathrm{HO}$ : the value of the obs chi-square statistic <the value of the chi-square table with a certain degree of confidence $(\alpha)$. If chi-square statistic $>$ the value of the chi-square table with a certain degree of confidence $(\alpha)$

\section{F Test (ANOVA): Model Fit Test}

The purpose of the F test (ANOVA) is to prove whether the independent variables included in the model have an influence on the dependent variable together (simultaneously).

\section{1) The hypothesis in this test is:}

Ho: $\beta=0$. which means variable $X$ has no effect on variable Y

Ha: $\beta \neq 0$. which means variable $X$ has an effect on variable $Y$ 2) The test statistic to be used is the F-test of the F-Snedecor distribution through the ANOVA list (analysis of variance).

3) The test criteria are:

- accept Ho, if F-count is smaller than $\mathrm{F}_{\text {-tabel }}\left(\mathrm{F}_{\text {-hitung }}>\mathrm{F}_{1-\alpha ; k \mathrm{k}-\mathrm{n}-\mathrm{k}-1)}\right)$.

- Ho reject, if $\mathrm{F}$-count is greater than $\mathrm{F}_{\text {-tabel }}\left(\mathrm{F}_{\text {-hitung }}>\mathrm{F}_{1-\text { - } \mathrm{k} ; \mathrm{k}: \mathrm{n}-\mathrm{k}-\mathrm{l}}\right)$.

\section{T test: Partial Test}

The purpose of the $\mathrm{T}$ test is to prove whether the independent variables included in the model have an influence on the dependent variable individually (partially).

1) The hypothesis in this test is:

Ho: $\beta \mathrm{i} \leq 0$. That is, there is no effect of the ith variable on the dependent variable.

Ha: $\beta \mathbf{i}>0$. This means that the ith variable affects the dependent variable.

2) The test statistic to be used is the t-test with the formula:

$\boldsymbol{t}_{i}=\frac{\beta_{i}}{\boldsymbol{S E}\left(\beta_{i}\right)}$

3) The test criterion is Ho reject, if p-value $<\alpha$ or t-count $>$ $\mathrm{t}$-table, where t-table $=\mathrm{t} 1-\alpha / 2 ; n-k-1$. If Ho is rejected, it means that there is a significant influence between the ith variable on the dependent variable.

\section{N. Coefficient of Determination (R2)}

The coefficient of determination or determination of the value of $\mathrm{R}^{2}$ is needed to determine the extent to which the independent variable can explain the dependent variable. The values range from 0 to 1 . If the value of $R^{2}$ is higher or closer to number 1 , the greater the independent variable $(\mathrm{X})$ so that it can explain the dependent variable (Y). The purpose of the analysis of the value of R-Square or $\left(\mathrm{R}^{2}\right)$ is to determine the extent to which the independent variable $(\mathrm{X})$ can explain the relationship between changes in the dependent variable (Y). done by regressing the independent variable against other there is heteroscedasticity, then $\mathrm{H} 1$ : the value of obs

The number of independent variables affects the properties of the R-Square. The relationship is one-way, that is, if there are more independent variables, the greater the R-Square value.

\section{RESULT AND DISCUSSION}

\section{A. Research Instrument Test Result}

The validity test is determined by comparing the Pearson Product Moment correlation value contained in the results of data processing. This test is assisted by the SPSS program which is seen in the CITS (Corrected Item-Total Correlation) column with a value of $r$ on the PMM (Pearson Product Poment) table. The critical value of correlation (r-table) with $\mathrm{n}$ of 30 respondents at the significance level (a) $5 \%$ is 0.361 in the pearson product moment $r$ table. The decision making criteria:

- If (r-count) is greater than (r-table) 0.361, it is declared valid - If (r-count) is smaller than (r-table) 0.361 , it is declared invalid

Table I. Results of the Research Instrument Variable Validity Test

\begin{tabular}{|c|c|c|c|c|}
\hline Indicator & Item & r-count & r-table & Remarks \\
\hline \multirow[t]{5}{*}{ Convenience (X1) } & 1 & 0,826 & 0,361 & Valid \\
\hline & 2 & 0,78 & 0,361 & Valid \\
\hline & 3 & 0,694 & 0,361 & Valid \\
\hline & 4 & 0,742 & 0,361 & Valid \\
\hline & 5 & 0,839 & 0,361 & Valid \\
\hline \multirow[t]{6}{*}{ Content (X2) } & 1 & 0,814 & 0,361 & Valid \\
\hline & 2 & 0,806 & 0,361 & Valid \\
\hline & 3 & 0,871 & 0,361 & Valid \\
\hline & 4 & 0,789 & 0,361 & Valid \\
\hline & 5 & 0,821 & 0,361 & Valid \\
\hline & 6 & 0,885 & 0,361 & Valid \\
\hline \multirow[t]{5}{*}{ Response (X3) } & 1 & 0,803 & 0,361 & Valid \\
\hline & 2 & 0,813 & 0,361 & Valid \\
\hline & 3 & 0,861 & 0,361 & Valid \\
\hline & 4 & 0,825 & 0,361 & Valid \\
\hline & 5 & 0,831 & 0,361 & Valid \\
\hline \multirow[t]{6}{*}{ Security (X4) } & 1 & 0,874 & 0,361 & Valid \\
\hline & 2 & 0,748 & 0,361 & Valid \\
\hline & 3 & 0,836 & 0,361 & Valid \\
\hline & 4 & 0,865 & 0,361 & Valid \\
\hline & 5 & 0,844 & 0,361 & Valid \\
\hline & 6 & 0,876 & 0,361 & Valid \\
\hline \multirow[t]{7}{*}{ Trust (X5) } & 1 & 0,838 & 0,361 & Valid \\
\hline & 2 & 0,891 & 0,361 & Valid \\
\hline & 3 & 0,884 & 0,361 & Valid \\
\hline & 4 & 0,884 & 0,361 & Valid \\
\hline & 5 & 0,869 & 0,361 & Valid \\
\hline & 6 & 0,897 & 0,361 & Valid \\
\hline & 7 & 0,809 & 0,361 & Valid \\
\hline \multirow[t]{10}{*}{ Purchase Decision (Y) } & 1 & 0,885 & 0,361 & Valid \\
\hline & 2 & 0,89 & 0,361 & Valid \\
\hline & 3 & 0,869 & 0,361 & Valid \\
\hline & 4 & 0,861 & 0,361 & Valid \\
\hline & 5 & 0,903 & 0,361 & Valid \\
\hline & 6 & 0,845 & 0,361 & Valid \\
\hline & 7 & 0,795 & 0,361 & Valid \\
\hline & 8 & 0,843 & 0,361 & Valid \\
\hline & 9 & 0,82 & 0,361 & Valid \\
\hline & 10 & 0,739 & 0,361 & Valid \\
\hline
\end{tabular}

Data Sources: Processed from the Questionnaire, 2020

Published By:

Blue Eyes Intelligence Engineering and Sciences Publication

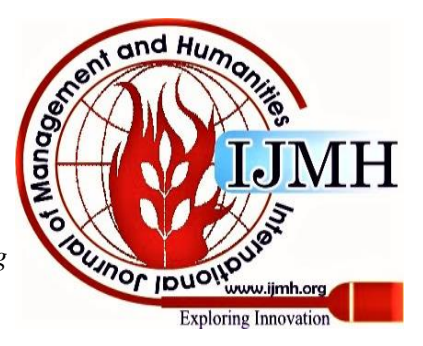




\section{Effect of E-Marketing on Purchase Decision Musicool Product of PT. Pertamina (Persero) RU III Palembang}

Table I shows that the indicators (items) used in this research variable can be declared valid and can be used as items in data collection because the indicators (items) in each of the variables are security, trust, response, convenience and content (independent variables) while the decision purchase (dependent variable) has a result of r-count greater than the r-table 0.361 .

\section{Reliability Test}

Reliability test aims to show how relatively consistent a measurement result is. Good categories of statements and questions are statements and questions that are clear, easily understood by correspondents, and have the same meaning even though they are submitted to different correspondents at different times. Reliability test using Cronbach's Alpha. An instrument is said to be reliable if the Cronbach's Alpha is greater than 0.60. There are five variables in the instrument reliability test, namely convenience (X1), content (X2), response (X3), security (X4), trust (X5) which are independent variables, while purchasing decisions $(\mathrm{Y})$ are the dependent variable. Decision-making criteria: If the value of Realibility Coefficients (Cronbach's Alpha) is greater than 0.60 (Alpha> 0.6), then the measured variable can be said to be reliable.

Table II. Reliability Test Results

\begin{tabular}{|l|c|c|c|c|c|}
\hline \multicolumn{1}{|c|}{ Indicator } & $\begin{array}{c}\text { Cronbach's } \\
\text { Alpha }\end{array}$ & $\begin{array}{c}\text { Cutt } \\
\text { Off }\end{array}$ & $\begin{array}{c}\text { N of } \\
\text { Case }\end{array}$ & $\begin{array}{c}\text { N of } \\
\text { Item }\end{array}$ & Remarks \\
\hline Convenience (X1) & 0,94089 & $>0,60$ & 30 & 5 & Reliable \\
\hline Content (X2) & 0,95009 & $>0,60$ & 30 & 6 & Reliable \\
\hline Response (X3) & 0,95685 & $>0,60$ & 30 & 5 & Reliable \\
\hline Security (X4) & 0,95819 & $>0,60$ & 30 & 6 & Reliable \\
\hline Trust (X5) & 0,97226 & $>0,60$ & 30 & 7 & Reliable \\
\hline $\begin{array}{l}\text { Purchase Decision } \\
\text { (Y) }\end{array}$ & 1,01414 & $>0,60$ & 30 & 10 & Reliable \\
\hline
\end{tabular}

Data Sources: Processed from the Questionnaire, 2020

Based on the results of the reliability test of the research variable instrument in Table 4.2, the results of the reliability test of the independent variable ease (X1), content (X2), response (X3), security (X4), trust (X5) indicate that the data obtained is reliable because of the value Cronbach's Alpha namely 0.94089, 0.95009, 0.95685, $0.95819,0.97226$ while the reliability test results of the dependent variable purchasing decision $(\mathrm{Y})$ show that the data obtained is reliable because the Cronbach's Alpha value is 1.01414 .

\section{Normality test}

In order to determine whether the data obtained is running normally or not, a data normality test is performed. The normality test of the sample uses the Komogrov-Smirnov test by setting the degree of confidence (a) of 5\% (Prayitno, 2013: 71). The results of the normality test are shown in the table as follows:

Table III. Normality Test Results

\begin{tabular}{|l|c|l|c|l|}
\hline \multirow{2}{*}{ Test of Normality } & \multicolumn{2}{|c|}{ Sig. } & $\begin{array}{c}\text { Kolmogrov- } \\
\text { Smirnov }\end{array}$ & \multirow{2}{*}{ Remarks } \\
\cline { 3 - 5 } & \multicolumn{2}{|c|}{ Cutt Off } & \\
\hline Convenience (X1) & 0,106 & $>$ & 0,05 & Normal \\
\hline Content (X2) & 0,246 & $>$ & 0,05 & Normal \\
\hline Response (X3) & 0,678 & $>$ & 0,05 & Normal \\
\hline Security (X4) & 0,333 & $>$ & 0,05 & Normal \\
\hline Trust (X5) & 0,235 & $>$ & 0,05 & Normal \\
\hline Purchase Decision (Y) & 0,111 & $>$ & 0,05 & Normal \\
\hline
\end{tabular}

Data Sources: Processed from the Questionnaire, 2020

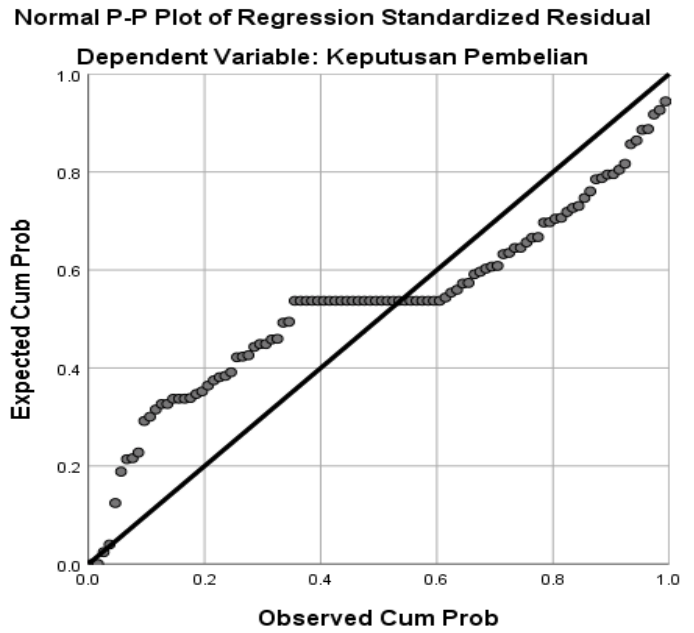

The graph above explains that the data is running normally. This is evidenced by the distribution of data around the diagonal line and following the direction of the diagonal line. So it can be concluded that the regression meets the assumption of normality

\section{Multicollinearity Test}

The higher the tolerance value, the lower the degree of collinearity that occurs, while for VIF, the lower the VIF, the lower the degree of collinearity that occurs. The limit of the maximum value of VIF which is usually used to justify the presence of collinearity is 10. The definition of the multicollinearity assumption is a condition in which there is an almost perfect linear relationship between the independent variables in the model.

Table IV. MulticolinearityTest Results

\begin{tabular}{|c|l|c|c|c|c|}
\hline No & Variabel & VIF & $\begin{array}{c}\text { Cut } \\
\text { t } \\
\text { Off }\end{array}$ & Remarks \\
\hline 1 & $\begin{array}{l}\text { Convenience } \\
(\mathrm{X} 1)\end{array}$ & 3.966 & $<$ & 10 & $\begin{array}{c}\text { Multicollinearity does } \\
\text { not occur }\end{array}$ \\
\hline 2 & $\begin{array}{l}\text { Content } \\
\text { (X2) }\end{array}$ & 6.463 & $<$ & 10 & $\begin{array}{c}\text { Multicollinearity does } \\
\text { not occur }\end{array}$ \\
\hline 3 & $\begin{array}{l}\text { Response } \\
(\mathrm{X} 3)\end{array}$ & 5.301 & $<$ & 10 & $\begin{array}{c}\text { Multicollinearity does } \\
\text { not occur }\end{array}$ \\
\hline 4 & $\begin{array}{l}\text { Security } \\
\text { (X4) }\end{array}$ & 6.125 & $<$ & 10 & $\begin{array}{c}\text { Multicollinearity does } \\
\text { not occur }\end{array}$ \\
\hline 5 & Trust (X5) & 4.738 & $<$ & 10 & $\begin{array}{c}\text { Multicollinearity does } \\
\text { not occur }\end{array}$ \\
\hline
\end{tabular}

Data Sources: Processed from the Questionnaire, 2020

Table 4.13 shows that the VIF value is less than 10 , this explains that there is no multicollinearity between the independent variables

\section{Heteroscedasticity Test}

By looking at the SPSS output on the scatter diagram, heteroscedasticity problems can be detected. The results of the heteroscedasticity test are illustrated in the following graph. 


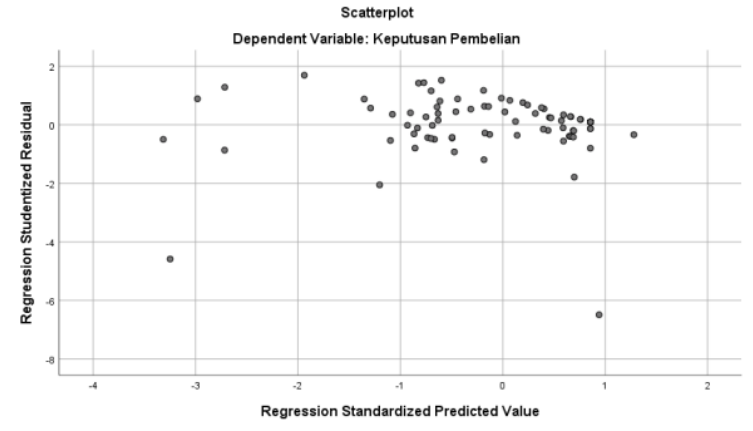

According to the results of the heteroscedasticity test in the image above shows that there is no heteroscedasticity in the test of this study, this is due to the distribution of data on the test results that do not form a certain line / unclear pattern and well-known points above and below zero on the Y line.

Multiple Linear Regression Analysis

Table V. Hasil Uji Analisis Regresi Linier Berganda

\begin{tabular}{|c|c|c|c|c|c|c|}
\hline \multicolumn{7}{|c|}{ Coefficients $^{\mathrm{a}}$} \\
\hline & \multirow{2}{*}{ Model } & \multicolumn{2}{|c|}{$\begin{array}{l}\text { Unstandardized } \\
\text { Coefficients }\end{array}$} & \multirow{2}{*}{$\begin{array}{c}\begin{array}{c}\text { Standardized } \\
\text { Coefficients }\end{array} \\
\text { Beta } \\
\end{array}$} & \multirow{2}{*}{ t } & \multirow{2}{*}{ Sig. } \\
\hline & & B & $\begin{array}{l}\text { Std. } \\
\text { Error }\end{array}$ & & & \\
\hline \multirow[t]{6}{*}{1} & (Constant) & 6.497 & 1.715 & & 3.789 & .000 \\
\hline & Convenience & .239 & .715 & .296 & 3.368 & .001 \\
\hline & Content & .277 & .087 & .293 & 3.162 & .002 \\
\hline & Response & .225 & .077 & .250 & 2.916 & .004 \\
\hline & Security & .417 & .349 & .220 & 2.815 & .037 \\
\hline & Trust & .704 & .270 & .423 & 2.608 & .011 \\
\hline
\end{tabular}

Data Sources: Processed from the Questionnaire, 2020

According to the test results of multiple linear regression analysis in table $\mathrm{v}$ shows the results of a positive constant value of 6,497, which means that there is a positive influence between variable $\mathrm{X} 1$ with a value of 0.239 , variable $\mathrm{X} 2$ with a value of 0.277 , variable $X 3$ with a value of 0.225 , variable $\mathrm{X} 4$ with a value of 0.417 , variable $\mathrm{X} 5$ with a value 0.704 to variable Y. Thus, variable Y (purchase decision) is strongly influenced by the variables of convenience, content, response, security and trust.

Correlation Coefficient (R) and Coefficient of Determination $\left(\mathbf{R}^{2}\right)$

Table VI. Result of Correlation Coefficient (R) and Coefficient of Determination $\left(\mathbf{R}^{2}\right)$

\begin{tabular}{|r|c|r|r|r|}
\hline \multicolumn{5}{|c|}{ Model Summary $^{\mathbf{b}}$} \\
\hline Model & R & R Square & $\begin{array}{c}\text { Adjusted } \\
\text { R Square }\end{array}$ & $\begin{array}{c}\text { Std. Error } \\
\text { of the } \\
\text { Estimate }\end{array}$ \\
\hline 1 & $0.691^{\mathrm{a}}$ & 0.478 & 0.450 & 451.449 \\
\hline
\end{tabular}

Data Sources: Processed from the Questionnaire, 2020

Based on the results of the Correlation Coefficient Test (R) and the Coefficient of Determination (R2) in the table above shows that there is influence of the convenience, content, response, security and trust variables on purchasing decisions is 0.691 or $69.1 \%$. The amount of the R square (R2) number is 0.478 or $47.8 \%$. This figure is used to see how the convenience, content, response, security and trust possessed by the online media platform for Musicool products PT. Pertamina.

This figure means how the variables of convenience, content, response, security and trust provide the good feedback and are needed to explain the purchase decision on the Musicool product media platform and collectively it is $47.8 \%$ while the remaining $52.2 \%$ is influenced by factors. other.

\section{Model Feasibility Test (F Test)}

Table VII. Model Feasibility Test Results (F Test)

\begin{tabular}{|c|c|c|c|c|c|c|}
\hline \multicolumn{7}{|c|}{ ANOVA $^{a}$} \\
\hline & Model & $\begin{array}{l}\text { Sum of } \\
\text { Squares }\end{array}$ & df & $\begin{array}{c}\text { Mean } \\
\text { Squar } \\
\text { e }\end{array}$ & $\mathbf{F}$ & Sig. \\
\hline \multirow{3}{*}{1} & $\begin{array}{l}\text { Regressi } \\
\text { on }\end{array}$ & $\begin{array}{r}1.752 .17 \\
9\end{array}$ & 5 & $\begin{array}{r}350.43 \\
6\end{array}$ & $\begin{array}{r}17.19 \\
5\end{array}$ & $.000^{\mathrm{b}}$ \\
\hline & Residual & $\begin{array}{r}1.915 .78 \\
1\end{array}$ & $\begin{array}{l}9 \\
4 \\
\end{array}$ & 20.381 & & \\
\hline & Total & $\begin{array}{r}3.667 .96 \\
0\end{array}$ & $\begin{array}{l}9 \\
9\end{array}$ & & & \\
\hline
\end{tabular}

Data Sources: Processed from the Questionnaire, 2020

According to the results of the F test in table VII above, the calculated $F$ value is 17,195 which indicates that it is greater than the $F$ value of table 2.47 which means that the increased variables, content, response, and trust together have a significant influence on the purchasing decision variable. This result is also with a significant value of the $F$ test of 0.000 or sig $0.000<0.05$ which indicates that the variables (X1), content (X2), response (X3), security (X4) and trust (X5) are together. significant effect on purchase decisions $(\mathrm{Y})$.

\section{Significant Test for Individual Parameters (t test)}

Table VIII. t Test Results

\begin{tabular}{|c|c|c|c|c|c|c|}
\hline \multicolumn{7}{|c|}{ Coefficients $^{\mathrm{a}}$} \\
\hline & \multirow{2}{*}{ Model } & \multicolumn{2}{|c|}{$\begin{array}{l}\text { Unstandardized } \\
\text { Coefficients }\end{array}$} & \multirow{2}{*}{$\begin{array}{c}\begin{array}{l}\text { Standardized } \\
\text { Coefficients }\end{array} \\
\text { Beta } \\
\end{array}$} & \multirow{2}{*}{$t$} & \multirow{2}{*}{ Sig. } \\
\hline & & B & $\begin{array}{l}\text { Std. } \\
\text { Error }\end{array}$ & & & \\
\hline \multirow[t]{6}{*}{1} & (Constant) & 6.497 & 1.715 & & 3.789 & .0000 \\
\hline & Convenience & .239 & .715 & .296 & 3.368 & .001 \\
\hline & Content & .277 & .087 & .293 & 3.162 & .002 \\
\hline & Response & .225 & .077 & .250 & 2.916 & .004 \\
\hline & Security & .417 & .349 & .220 & 2.815 & .037 \\
\hline & Trust & .704 & .270 & .423 & 2.608 & .011 \\
\hline
\end{tabular}

a. Dependent Variable: Purchase Decision

Data Sources: Processed from the Questionnaire, 2020

Based on the calculation of the test results for the significance of individual parameters (t test) in Table VIII it can be described as follows :

1) Convenience variable (X1) has a B (beta) effect of 0,239 with a sig. value of 0,001 which is a little than 0,05 . Which means that the variable $\mathrm{X} 1$ has a significant effect on variable $\mathrm{Y}$

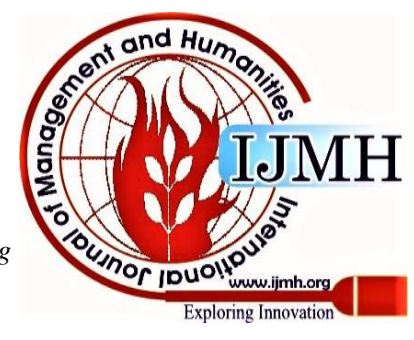




\section{Effect of E-Marketing on Purchase Decision Musicool Product of PT. Pertamina (Persero) RU III Palembang}

2) Product content variable (X2 has a B (beta) effect of 0,277 with a sig. value of 0,002 which is a little 0,05 . Which means that the variable $\mathrm{X} 2$ has a significant effect on variable $Y$

3) Response variable (X3 has a B (beta) effect of 0,225 with a significance value of 0,004 which is a little 0,005 . Which means that the variable X3 has a significant effect on variable $\mathrm{Y}$

4) Safety variable (X4) has a B (beta) effect of 0,417 with a significance value of 0,037 which is a little 0,05 . Which means that the variable $\mathrm{X} 4$ has a significant effect on variable Y.

5) Trust variable (X5), has a B (beta) effect of 0,704 with a significance value of 0,011 which is a little than 0,05 . Which means that the variable X5 has a significant effect on variable $\mathrm{Y}$

\section{RESEARCH RESULTS FOR EACH VARIABLE}

\section{A. Effect of Ease in E-Marketing on Purchasing Decisions}

Ease variable has a positive \& significant effect on purchasing decision. From the results of the study, the coefficient for the convenience variable is 0.239 with a significant value of 0 , the value will be significant at the sig. value 0,05 because it is smaller than 0.05 . Thus, convenience has a positive and significant effect on purchasing decisions.

Based on research and questionnaire results from several respondents, it was found that consumers already felt that the ease of e-marketing media platform for Musicool products has been very good. Consumers feel that the media platform in e-marketing of Musicool products is easy to operate and easy to find information about products, and easy to transact.

This research is in accordance with the results of research (Immanuel, 2020); (Mailal et al., 2020); (Randy et al., 2019); (Nursakinah et al., 2019); (Indah, 2019); (Nawangsari et al., 2018); (Wawan et al., 2016); (Yoon, 2015); (Denni et al., 2015) which supports that the convenience variable has a positive effect on purchasing decisions.

\section{B. Effect of Content in E-Marketing on Purchasing Decisions}

Content variable has a positive \& significant effect on purchasing decision. From the research results, the coefficient for the content variable is 0.277 with a significant value of 0.002 the value will be significant at the sig. value 0,05 because it is smaller than 0.05 . Thus, content has a positive and significant effect on purchasing decision.

Based on research and questionnaire results from several respondents, it was found that consumers already felt that the content in the e-marketing media platform Musicool products has been very good. Consumers feel that the content presented is very interactive and easy to understand.

This research is in accordance with the results of research (Immanuel, 2020); (Christian et al., 2019); (Sudarsono et al., 2019); which supports that content variables have a positive effect on purchasing decisions.

\section{Effect of Response in E-Marketing on Purchasing Decisions}

Response variable has a positive \& significant effect on purchasing decisions. From the research results, the coefficient for the response variable is 0,225 with a significant value of 0.004 the value will be significant at the sig. value 0,05 because it is smaller than 0.05 . Thus, that the response has a positive and significant effect on purchasing decisions.

Based on research and questionnaire results from several respondents, it was found that consumers already felt that the response to the e-marketing media platform for Musicool products has been very good. Consumers feel that admin on e-marketing of Musicool products has responded well to consumers.

This research is in accordance with the results of research (Immanuel, 2020) which supports that content variables have a positive effect on purchasing decisions.

\section{Effect of Security in E-Marketing on Purchasing Decisions}

Security variable has a positive \& significant effect on purchasing decisions. From the research results, the coefficient for the security variable is 0,417 with a significant value of 0.0037 the value will be significant at the sig. value 0,05 because it is smaller than 0.05 . Thus, that the response has a positive and significant effect on purchasing decisions.

Based on research and questionnaire results from several respondents, it was found that consumers already felt that the security in the e-marketing media platform for Musicool products has been very good. Consumers feel that if they use Musicool's product media platform in e-marketing, their privacy data will be protected and not misused, for example, such as email, password etc.

This research is in accordance with the results of research (Immanuel, 2020); (Ilham et al., 2016); (Michael, Eva., 2016); (Indra, 2018); which supports that content variables have a positive effect on purchasing decisions.

The Effect of Trust in E-Marketing on Purchasing Decisions

Trust variable has a positive \& significant effect on purchasing decisions. From the research results, the coefficient for the security variable is 0,704 with a significant value of 0.011 the value will be significant at the sig. value 0,05 because it is smaller than 0.05. Thus, that the response has a positive and significant effect on purchasing decisions. Based on research and questionnaire results from several respondents, it was found that consumers already felt that trust in the e-marketing media platform Musicool products has been very good. Consumers feel that the media platform, technicians, agents, workshops of Musicool products can be trusted. This research is in accordance with the results of research from (Immanuel, 2020); (Febriana, 2020); (Andy et al., 2020); (Mailal et al., 2020); (Abbas et al., 2019); (Indah, 2019); (Widarto, 2018); (Dadang, 2018); (Elisabeth et al., 2018); (Nawangsaaari, 2018); (Bayu, 2017); (Jasmine, 2017); (Michal, 2016); (Muslikh, 2017); (Ilham et al., 2016); (Setyo et al., 2017); (Penia et al., 2019); (Wawan, 2016); (Yoon, 2015); (Denni et al., 2015); which supports that the trust variable has a positive effect on purchasing decisions.
Published By:

Blue Eyes Intelligence Engineering and Sciences Publication (C) Copyright: All rights reserved.

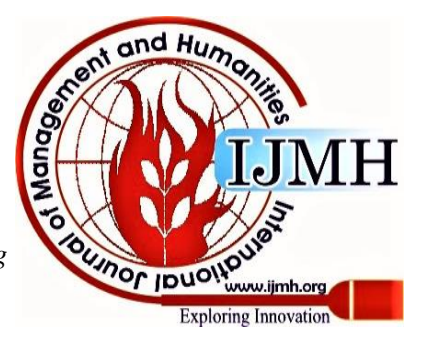




\section{E. Recapitulation of Research Results}

Table IX. Recapitulation of Research Results

\begin{tabular}{|c|c|}
\hline Hypothesis & Research Result \\
\hline $\begin{array}{l}\text { H0 : Convenience of } \\
\text { purchase decisions was } \\
\text { rejected }\end{array}$ & \multirow{2}{*}{$\begin{array}{c}\text { H1 : Convenience has a positive \& } \\
\text { significant effect on purchasing } \\
\text { decisions }\end{array}$} \\
\hline $\begin{array}{l}\text { Ha : Convenience of } \\
\text { purchase decisions } \\
\text { accepted }\end{array}$ & \\
\hline $\begin{array}{l}\text { H0 : Content of purchase } \\
\text { decisions was rejected }\end{array}$ & \multirow{2}{*}{$\begin{array}{l}\text { H2 : Content has a positive \& } \\
\text { significant effect on purchasing } \\
\text { decisions }\end{array}$} \\
\hline $\begin{array}{l}\text { Ha : Content of purchase } \\
\text { decisions accepted }\end{array}$ & \\
\hline $\begin{array}{l}\text { H0 : Response of purchase } \\
\text { decisions was rejected }\end{array}$ & \multirow{2}{*}{$\begin{array}{l}\text { H3 : Response has a positive \& } \\
\text { significant effect on purchasing } \\
\text { decisions }\end{array}$} \\
\hline $\begin{array}{l}\text { Ha : Response of purchase } \\
\text { decisions accepted }\end{array}$ & \\
\hline $\begin{array}{l}\text { H0 : Security of purchase } \\
\text { decisions was rejected }\end{array}$ & \multirow{2}{*}{$\begin{array}{c}\text { H4 : Security has a positive \& } \\
\text { significant effect on purchasing } \\
\text { decisions }\end{array}$} \\
\hline $\begin{array}{l}\text { Ha : Security of purchase } \\
\text { decisions accepted }\end{array}$ & \\
\hline $\begin{array}{l}\text { H0 : Trust of purchase } \\
\text { decisions was rejected }\end{array}$ & \multirow{2}{*}{$\begin{array}{l}\text { H5 : Trust has a positive \& significant } \\
\text { effect on purchasing decisions }\end{array}$} \\
\hline $\begin{array}{l}\text { Ha : Trust of purchase } \\
\text { decisions accepted }\end{array}$ & \\
\hline
\end{tabular}

Data Sources: Processed from the Questionnaire, 2020

\section{CONCLUSIONS AND SUGGESTIONS}

\section{A. Conclusion}

Based on the results of the analysis and discussion in the previous chapter, this research can be concluded as follows:

1. Ease of variables in e-marketing has a positive and significant effect on purchasing decisions Musicool PT. Pertamina (Persero)

2. Content variables in e-marketing has a positive and significant effect on purchasing decisions for Musicool PT products. Pertamina (Persero)

3. The response variable in e-marketing has a positive and significant effect on purchasing decisions for Musicool PT. Pertamina (Persero)

4. Security variables in e-marketing in e-marketing has a positive and significant effect on purchasing decisions for Musicool PT products. Pertamina (Persero)

5. Trust variable in e-marketing in e-marketing has a positive and significant effect on purchasing decisions for Musicool PT products. Pertamina (Persero)

\section{B. Suggestions}

As for the suggestions that researchers can submit to the company PT. Pertamina (Persero) and further researchers related to e-marketing, namely as follows::

1. For PT. Pertamina

a. The trust given by Pertamina's marketing team is good for consumers, but Musicool technicians, agents and product workshops also need to improve the process of sending products that have been ordered by consumers so that they are fast on time so that consumers don't take long to enjoy the results of service.

b. The content provided by Pertamina's marketing is good for consumers, but in the future Pertamina can make video content that has a short duration but the information provided is very clear.

2. For Further Researchers

a. In this study, there are limitations, namely the researcher only uses the variables of security, trust, response,

convenience, content and purchase decisions. It is expected that further researchers can add many other variables such as celebrity endorse, WOM, loyalty, company image, customer loyalty and others.

b. Suggestions for further researchers, it is expected to increase the number of research samples, expand the research sample and increase the time period for conducting research.

\section{REFERENCES}

1. Andy et al., (2020). Pengaruh Kepercayaan dan Kenyamanan Terhadap Keputusan Pembelian Online (Studi Pada Pelanggan Website Ride Inc). Jurnal Administrasi Bisnis (JAB)| Vol. 8 No. 2 Maret 2014

2. Augusty Ferdinand, DBA. (2019). Metode Penelitian Manajemen. Semarang: Badan Penerbit Universita Diponegoro.

3. A Sussanto. "Pengaruh Promosi, Harga dan Inovasi Produk Terhadap Keputusan Pembelian Pada Batik Tulis Karangmlati Demak” (Skripsi Universitas Negeri Semarang, Semarang, 2013).

4. Badan Pusat Statistik Jakarta Indonesia. (2018). Statistik Telekomunikasi Indonesia 2018. Jakarta Pusat : Badan Pusat Statistik.

5. Banyu B. (2019). Pengaruh Content Marketing pada Viral Marketing dan customer engagement pengguna Tokopedia di Yogyakarta. Skripsi. Fakultas Ekonomi. Manajemen. Universitas Sanata Dharma. Yogyakarta

6. Bayu A.P.W.P. (2017). The effect of trust, risk, and web design on consumer intention by means of consumer attitude to purchase online. Journal of applied management vol. 15 no. 3 semptember 2017 indexed in google scholar

7. Bethani dan Donni. (2020). Effects of E-Marketing and Social Media Marketing on E-commerce Shopping Decisions. Jurnal Manajemen Indonesia (Vol. 20(1), pp. 76-82, 2020)

8. Carter, Ben; Brooks, Gregory; Catalano, Frank; Smith, Bud. (2007) Digital Marketing for Dummies. John Wiley \& Sons. ISBN 9780470057933

9. Cholifatun Nisak. (2016). Pengaruh harga, keragaman, model produk, kualitas informasi dan kepercayaan terhadap keputusan pembelian online pada toko tas online sabilla store. Jurnal Universitas Diponegoro

10. Christian et al. (2019). Beauty Influencer's User-Generated Content On Instagram: Indonesian Millennials Context. International Journal Of Scientific \& Technology Research Volume 8, Issue 09, September 2019

11. Dadang. (2018). The Analysis of Ease of Use, Trust, and Website Quality towards Purchasing Decision in Lazada.co.id. Indonesian Journal of Business and Economics Vol. 1 Issue 1, June 2018

12. Denni Aryanto, Heru Susilo, Riyadi. (2015). Pengaruh Kemudahan dan Kepercayaan menggunakan E-Commerce Terhadap Keputusan Pembelian (Survei Pada Konsumen www.petersaysdenim.com). Jurnal Administrasi Bisnis (JAB) vol. 22 no. 1 Mei 2015

13. Desy \& Apriatni. (2019). Pengaruh Kemudahan, Kualitas Informasi dan Kepercayaan Terhadap Keputusan Pembelian Secara Online Pada situs Lazada. Jurnal Universitas Diponegoro

14. Elisabeth, Funnisa, Aari. (2018). The influence of promotion, trust, and convience to online purchase decisions. International Journal of mechanical engineering and technology (IJMET) Vol. 9, Issue 10 October 2018

15. Febriana. (2020). Consumer Trust in Online Purchase Decision International Journal of Multidisciplinary Research (IJMR) Vol. 6 Issue 2 February 2020 DOI 10.36713

16. GM Susanto. (2017). The Power of Digital Marketing. Jakarta: Penerbit PT Elex Meida Komputindo

17. Gorys Keraf. (1994). KOMPOSISI. Jakarta: Percetakan IKRAR MANDIRI ABADI.

18. Ilham Tugiso, Andi Tri Haryono, Maria M Minarsih. (2016). Pengaruh Relationship Marketing, Keamanan, Kepercayaan dan Kualitas Pelayanan Terhadap Keputusan Pembelian Online Shop dan loyalitas konsumen sebagai variable intervening. Jurnal of management. Volume 2 no 2 maret 2016

19. Immanuel, (2020). Analisis E-Marketing terhadap keputusan pembelian konsumen secara online. Journal of Business and Banking ISSN 2088-7841Volume 9 Number 2

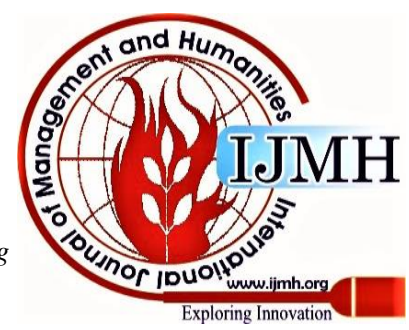




\section{Effect of E-Marketing on Purchase Decision Musicool Product of PT. Pertamina (Persero) RU III Palembang}

20. Indah \& Widyastuti. (2019). Pengaruh Kepercayaan dan Kemudahan Terhadap Keputusan Belanja Online (Studi Pada Pengguna Tokopedia). Jurnal Ilmu Manajemen Volume 7 Nomor 2 - Jurusan Manajemen Fakultas Ekonomi Universitas Negeri Surabaya

21. Indra Ade Irawan. (2018). Effect of trust, convenience, security and quality of service on online purchase decision. Jurnal Ekonomi / Volume XXIII, No. 01, Maret 2018:114-122

22. Jasmine et al. (2017). Consumer Purchase Decision in Instagram Stores: The Role of Consumer Trust. ISBN: 978-0-9981331-0-2 CCBY-NC-ND

23. Juliandi A, Irfan, Manurung S. 2014. Metodologi Penelitian Bisnis: Konsep dan Aplikasi. Medan: UMSU Press.

24. Kotler, Amstrong (2004). Prinsip-prinsip Pemasaran, Erlangga, Jakarta.

25. Lubiana \& Achmad. (2018). Pengaruh Social Media Marketing Terhadap Keputusan Pembelian (Survei Online pada Mahasiswa Sarjana Jurusan Ilmu Administrasi Bisnis Angkatan 2014/2015 Fakultas Ilmu Administrasi Universitas Brawijaya yang Membeli Starbucks Menggunakan LINE). Jurnal Administrasi Bisnis (JAB) Vol. 58 No. 1 Mei 2018

26. Mailal et al., (2020). The Effect Of Ewom, Ease Of Use And Trust On Purchase Decisions (Study On Tokopedia Application Users). Jurnal Minds: Manajemen, Ide dan Inspirasi June, Vol. 7 No.1, 2020: 39-52

27. Michal \& Eva. (2016). Trust and Security as Significant Factors Influencing On-Line Buying Behavior in The Czech Republic. EM Journal, Vol. 8 Issue 2, 2016 ISSN: 1804-1299 (print), 1805-353X

28. Muhammad Said Jundi. (2016). Analisis Pengaruh Kualitas Layanan, Citra Merek dan Kepercayaan Terhadap Keputusan Pembelian Melalui Nilai yang Dipersepsikan Sebagai mediasi pada toko online Lazada.co.id (Studi pada konsumen Lazada.co.id Kota semarang). Jurnal Universitas Diponegoro

29. Nindy dan Saryadi. (2020). Pengaruh Kemudahan Akses Dan Diskon Terhadap Keputusan Pembelian Pada Situs Online Tiket.Com. Jurnal Riset Akuntansi dan Keuangan Indonesia Vol.5 No.1 April 2020

30. Nursakinah et al., (2019). The Influence Of Perceived Ease Of Use, Discount, And Perceived Usefulness On Intention To Use Grab Aplication And It's Impact On Purchase Decision Of Grab Services. The International Journal of Accounting and Business Society Vol. 27, No. 2

31. Nursiam, (2020). Simplicity, Price, Quality of Service and Safety Towards The Decision to Purchase Products Through Shopee.id Application. Jurnal Riset Akuntansi dan Keuangan Indonesia Vol.5 No.1

32. Penia Anggraini, Putu Nina Madiawati. (2016). Pengaruh Kepercayaan dan Kualitas Informasi Tehadap Keputusan Pembelian Secara Online Pada Situs www.traveloka.com. e-Proceeding of management vol 3, No 2 Agustus 2016 page 1884 ISSN: 2355-9357

33. Philip Kotler, Hermawan Kartajaya \& Iwan Setiawan. (2019) Marketing 4.0 bergerak dari tradisional ke digital. Jakarta: Penerbit PT Gramedia Pustaka Utama.

34. Randy, Dian, Tanti. (2019). Effect of Perceived Ease of Use, Word of Mouth Communication, and Brand Image on Decision to Use Lazada E-Commerce Services. International Journal Of Multicultural and Multireligious Understanding

35. Riko Ashari, Widiyanto. (2016). Pengaruh Kepercayaan dan risiko terhadap keputusan pembelian melalui sikap pengguna pada situs belanja online lazada.com (Studi pada mahasiswa fakultas ilmu sosial dan ilmu politik universitas diponegoro semarang). Jurnal Universitas Diponegoro

36. Rizana Oktari, Zakaria Wahab dan Marlina Widiyanti. (2020). Pengaruh Bauran Promosi Terhadap Keputusan Konsumen Dalam Menggunakan Grab-Food Di Palembang. International Journal of Management and Humanities (IJMH) ISSN: 2394 - 0913, Volume-4 Issue-5, January 2020

37. Rukhsana K., Ghulam, haroon. (2018) How does website quality and trust towards website influence online purchase intention. Pakistan Journal of Commerce and Social Sciences 2018. Vol. 12 (3), 909-934

38. Ryan, Damian; Jones, Calvin. (2009). Understanding digital marketing: marketing strategies for engaging the digital generation. Kogan Page, ISBN 978-0749453893

39. Sri Nawangsari, Yelsi Karmayanti. (2018). Pengaruh Kepercayaan, Kemudahan dan Kulaitas Informasi terhadap keputusan pembeluan melalui media sosia instagram (Studi kasus pada online shop YLK.Store). Jurnal Fakultas Ekonomi Universitas Gunadarma

40. Sudarsono et al. . (2017). Big Data and Content Marketing on Purchase Decisions Online In Indonesia. IOSR Journal of Business and Management (IOSR-JBM)e-ISSN: 2278-487X, p-ISSN: 2319-7668. Volume 22, Issue 2. Ser. III (February. 2020), PP 42-46

41. Sugiyono. (2006). Metode Penelitian Bisnis. Bandung: Penerbit Alfabeta, CV. Jl. Gegerkalong Hilir Bandung
42. Wawan Hermanto, Indah Fatmawati. (2016). Analisis pengaruh kepercayaan, kemudahan dan kualitas informasi terhadap keputusan pembelian secara online. Jurnal Universitas Muhammadiyah Yogyakarta

43. Winarno. 2015. Analisis Ekonometrika dan Statistik dengan Eviews. Yogyakarta: Pustaka Pelajar.

44. Yoon C. Cho . (2015). Exploring Factors That Affect Usefulness, Ease Of Use, Trust, And Purchase Intention In The Online Environment. International Journal of Management \& Information Systems first quarter 2015 vol. 19, number 1

\section{AUTHORS PROFILE}

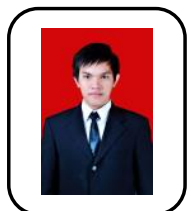

Ferdi Kurniawan, S.Kom is a graduate of Computer Science and is currently registered as a Master of Management Student, Faculty of Economics Sriwijaya University Palembang, Indonesia. Email: k.ferditz@gmail.com

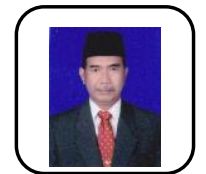

Dr. Zakaria Wahab, M.B.A is a Lecturer of Magiste Management Economic Faculty, Sriwijaya University, Palembang Indonesia

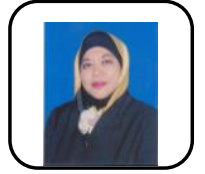

Hj. Marlina Widiyanti, S.E, S.H., M.M., M.H., Ph.D is a Head of Magister Management Economic Faculty, Sriwijaya University, Palembang Indonesia

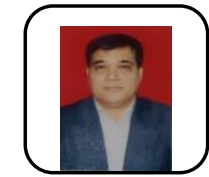

H. Muchsin Saggaff Shihab, M.B.A., Ph.D is a Lecturer of Magister management Economic Faculty, Sriwijaya University, Palembang Indonesia

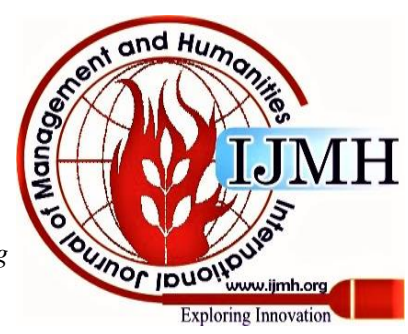

